\title{
Earnings Management, Good Corporate Governance, Size of Public Accounting Firm on The Integrity of Financial Report
}

\author{
Khayatul Izzah ${ }^{1}$, Nawirah² \\ 1,2Universitas Islam Negeri Maulana Malik Ibrahim Malang, Indonesia
}

\begin{abstract}
A R T I C L E I N F O
Article History:

Received

Revised

Publish

Keywords:

Earnings Management; Good Corporate Governance; Integrity of Financial Report; Size of Public Accounting Firm
\end{abstract}

DOI:

\section{INTRODUCTION}

Accounting information in the form of financial report, which have high integrity will be relied upon because it is an honest presentation. Therefore, it will allow users of accounting information to rely on the information. Financial report that has high integrity has the ability to influence the decisions of financial report readers in making decisions, including in terms of investing. Investors will be attracted to the company if the company's profits look large which means that the company is believed to be able to achieve its goals by earning profits on the company.

The size of the integrity of financial statements can be divided into two, namely measured by conservatism and the existence of manipulation of financial statements which is usually measured by earnings

\section{A B S T R A C T}

Implementation of Good Corporate Governance (GCG) which is believed to minimize the occurrence of fraud to achieve the integrity of financial report, GCG is proxied by institutional ownership, independent commissioners, and audit committees. Public Accounting Firm (KAP) as a variable which is an external auditor as an intermediary if there is a difference of opinion with the company's internal parties. The purpose of this study is to find out the effect of Earnings Management, Institutional Ownership, Independent Commissioners, Audit Committees, Size of Public Accounting Firms on the Integrity of Financial Report in mining companies. The researcher uses mining companies in Indonesia for the 2015-2019 period as the population with 22 companies as the research samples. Panel data analysis Eviews 9.0 software is used as a research method. The results of this study prove that the variables have a significant effect are the audit committee, meanwhile earnings management, institutional ownership, independent commissioners, size of public accounting firm on the integrity of the financial report have no significant effect.

\section{A B S T R A K}

Penerapan Good Corporate Governance (GCG) yang diyakini dapat meminimalisir terjadinya fraud untuk mencapai integritas laporan keuangan, GCG diproksikan dengan kepemilikan institusional, komisaris independen, dan komite audit. Kantor Akuntan Publik (KAP) sebagai variabel yang merupakan auditor eksternal sebagai perantara jika terjadi perbedaan pendapat dengan pihak internal perusahaan. Tujuan penelitian ini adalah untuk mengetahui pengaruh Manajemen Laba, Kepemilikan Institusional, Komisaris Independen, Komite Audit, Ukuran Kantor Akuntan Publik terhadap Integritas Laporan Keuangan pada perusahaan pertambangan. Peneliti menggunakan perusahaan pertambangan di Indonesia periode 2015-2019 sebagai populasi dengan sampel penelitian sebanyak 22 perusahaan. Analisis data panel Perangkat lunak Eviews 9.0 digunakan sebagai metode penelitian. Hasil penelitian ini membuktikan bahwa variabel yang berpengaruh signifikan adalah komite audit, sedangkan manajemen laba, kepemilikan institusional, komisaris independen, ukuran kantor akuntan publik terhadap integritas laporan keuangan tidak berpengaruh signifikan. 
management. The characteristics of information in the principle of conservatism can be one of the factors to improve the integrity of the financial statements. Conservatism itself is synonymous with understate financial statements which have less risk than overstate financial statements. Lubis, Fujianti, \& Amyulianthy (2018) Conservatism is a principle accounting that emphasizes prudence when responding to the future (Revenue), so as to minimize material errors in presentation of financial statements. Measurement of conservatism is said to be more reliable, it is agree with the research conducted by Nelly (2016) that the report The financial statements are more reliable if the financial statements are conservative and not overstate so that the information presented in the financial statements does not cause harm to the party using the the accounting information. So it is more advisable to use conservatism in measuring the integrity of financial statements.

Manipulation in financial report often occurs. It is caused by several factors such as the interest of management to increase or decrease the profit allowed in accounting standards. Based on the information obtained, an investor does not only judge from his profit to be able to trust the integrity of a financial report, but from several things. Some of these things are in the form of Good Corporate Governance, Earnings Management, and the Quality of Public Accounting Firms as independent variables whose influence will also be seen on the Integrity of Financial report.

The first difference in this study based on the independent variables used. Previous research does not make an independent variable that will be carried out by the author in one study, while the research that will be carried out by the author is a combination of independent variables from previous studies that are still not saturated. Also, the difference with previous research based on the elements that exist in the independent variable Good Corporate Governance (GCG), in this study, only limited to elements of institutional ownership, independent commissioners and audit committees. Meanwhile, the managerial ownership variable which is included in Good Corporate Governance (GCG) is not used, because the results in previous studies show that managerial ownership always has a (constant) influence on the Integrity of Financial report, therefore it is not used in this study and only uses independent variables whose results are just not consistent.

The difference in the second study is based on the results of the research. On the variable Good Corporate Covernance proxied by institutional ownership, independent commissioners, and audit committees. According to research by Wardhani and Samrotun "(2020) that institutional ownership has a significant positive effect on the integrity of financial report, while according to Priharta's research (2017) that institutional ownership has a significant negative effect on the integrity of financial report. According to Priharta's research (2017) that independent commissioners have a significant positive effect on the integrity of financial report, Mirda \& Sri's (2014) research states that independent commissioners have an insignificant positive influence on the integrity of financial report, while according to Siahaan (2017)" states the opposite, that independent commissioners have an insignificant negative effect on the integrity of the financial report.

In the audit committee variable, according to Siahaan's research (2017)", it states that the audit committee has a significant positive effect on the integrity of financial report, while according to Irawati \& Fakhruddin (2016) research, it is inversely proportional, which in this study states that the audit committee has an insignificant negative effect on the integrity of financial report. While the independent variable earnings management according to research by Lubis, Fujianti, \& Amyulianthy (2018) has a positive and insignificant effect on the integrity of financial report and according to research by Tawakal Putra \& Muid (2012), it is inversely proportional, stating that earnings management has a significant negative effect on the integrity of financial report . Similarly, the variable size of the public accounting firm, which in the research of Awalin, et al (2020) that the size of the public accounting firm has a significant positive effect on the integrity of financial report, in the research of Lubis, Fujianti, \& Amyulianthy (2018) states that the size of the public accounting firm has the positive effect is not significant on the integrity of financial report, while according to Siahaan (2017)" states the opposite, that the size of the public accounting firm has an insignificant negative effect on the integrity of financial report.

Based on the information obtained above, it turns out that previous studies have obtained different results. Because of this inconsistency, the researcher's motivation is to re-examine independent variables such as proxy Good Corporate Governance (institutional ownership, independent commissioners and audit committees), Earnings Management, and Public Accounting Firm Size and will see their effect on the dependent variable of financial report integrity. 
Apart from the inconsistency of the results of previous studies, the fact that the assessment of the financial report integrity cannot only be seen from the high and low profits. The presentation of the integrity of the financial report can also be seen from the extent to which the financial report are presented correctly and honestly, all information contained in the financial report can be accounted for by stakeholders and parties who have audited the financial report. This fact became the second motivation for conducting a research with this title to see what factors can affect financial report to be recognized for their integration.

The object used in this research is the Mining Sector. The mining sector was chosen by the researcher based on the suggestions from previous studies to conduct research in the non-manufacturing sector which has become the object of many previous studies. In addition, the reason for researchers to take objects in the mining sector because there are several cases including those that occurred in 2018 at PT. Toba Sejahtera due to weak Good Corporate Governance, suspected because the owner company has power and relationship political. By proving it, action arbitrarily abandoned the mine pit which according to the law should be a former mining pit restored and replanted. The purposes of this study are to determine whether earnings management has a significant negative effect on the integrity of financial report, to find out whether institutional ownership has a significant positive effect on the integrity of financial report, to find out whether independent commissioners have a significant positive effect on the integrity of financial report, to find out whether the audit committee has a significant positive effect on the integrity of financial report. Integrity of Financial Report, as well as knowing whether the Quality of Public Accounting Firms has a significant positive effect on the Integrity of Financial Report.

\section{LITERATURE REVIEW}

Agency theory (Agency Theory) suggests that there are (contracts) working relationship between the party giving the authority, namely the investor as the principal with the party receiving the authority, namely the manager as agent (Jensen \& Meckling, 1976). This agency relationship, the investor (Principal) give authority to another party, namely the agent (manager) who is assessed have more ability to manage the company well. Party the principal makes a contract to reward the agent, then the agent makes a contract to carry out certain tasks for principal. Even though the two parties have mutual interests conflict at a certain time is called a conflict of interest (agency problem). Rahmawati (2017), agency theory states that there are ways to bridge the agency problem and asymmetric information, with the existence of corporate governance (Corporate Governance).

Hasanuddin (2020) the word Integrity comes from Latin, called integer; incorruptibility, firm adherence to a code of especially moral acristic values, called an attitude that firmly maintains principles, does not want corruption, and becomes the basis that is attached to oneself as moral values. Integrity is an action not just a word. Integrity when associated with financial report is information presented in financial report that are provided transparently without anything being covered up or commonly referred to as full disclosure.

Sulistyanto (2018) Earnings management is an opportunistic behavior carried out by a manager by playing with numbers in financial report in accordance with the goals to be achieved. There are two perspectives on earnings management, the first is an opportunist perspective, in the theory it is said that earnings management is part of fraud, but the second perspective regarding the information perspective, it is said that earnings management is not part of fraud, because the accounting method gives a manager the freedom to choose and using certain accounting methods, but in accordance with generally accepted accounting principles and procedures in order to improve company efficiency. Earnings management is hypothesized to have a negative effect on the integrity of financial report because earnings management is a playing with numbers in a financial report, then the behavior can be said to be an activity manipulation of financial report which will affect on the integrity financial report.

$H_{\mathrm{I}}$ : Earnings management has a significant negative effect on the Integrity of Financial Report

Good Corporate Governance is a good system and structure for managing a company that has the aim of increasing shareholder value and accommodating various parties with an interest in the company (stakeholders), such as shareholders, government, consumers, workers, and the wider community (Hasanuddin, 2020). The implementation of Good Corporate Governance serves as a bridge between individual interests, a company that has implemented Good Corporate Governance will minimize the occurrence of 
individual interests, so that the company can be ensured that it has been managed properly. In this study, the elements that will be measured against Good Corporate Governance including: institutional ownership, independent commissioners and audit committees.

Institutional ownership is ownership of company shares owned by institutions or companies such as insurance companies, investment companies, banks, and other institutional ownership (Siahaan, 2017). Institutional investors are shareholders who have a big influence on the company because the ownership of shares invested in a company is of great value (Khatijah, 2019). With institutional ownership, it can show strong Good Corporate Governance that can be used to monitor companies in general and earnings management practices, because institutional investors are also considered effective in monitoring the performance of managers.

$H_{2}$ : Institutional Ownership has a significant positive effect on the Integrity of Financial reports

Independent commissioners are members of the board of commissioners who come from outside parties and not affiliated with the board of directors, controlling shareholders and other members of the board of commissioners, and also free from business relationships or other relationships that may affect their ability to act independently or act solely in the interest of the company (Siahaan, 2017) . Independent Commissioners are said to be influential because independent commissioners can be a balancer in decision making and can also act as a mediator between minority parties and other related parties and can oversee manager policies and can provide advice to managers (Khatijah, 2019). Therefore, it can be concluded, if there is an independent commissioner in a company, then the financial report presented can be said to have integrity.

$H_{3}$ : Independent Commissioner has a significant positive effect on the Integrity of Financial reports

The Audit Committee is a committee formed by the board of commissioners and is responsible for assisting the board of commissioners. The audit committee consists of one or more members of the board of commissioners and can ask outsiders with various skills, other qualities, and experience needed to be able to achieve the objectives of the audit committee (Siahaan, 2017). Bradbudry et al 2004 in Siahaan (2017) the audit committee has the task of overseeing the financial reporting process by management, reviewing accounting policies, conducting internal control assessments, reviewing external reporting systems and also assessing regulatory compliance. From the duties of the audit committee, the audit committee has benefits including ensuring the openness and transparency of financial reports, disclosures made by management and the realization of justice for stakeholders (Khatijah, 2019). So that the presence of the audit committee can reduce fraud in the process of presenting financial report so that the integrity of financial report can be realized.

$H_{4}$ : The audit committee has a significant positive effect on the Integrity of Financial reports

Size is identical to the size of an object. The size of a public accounting firm is the basis for determining the size of a public accounting firm. A Public Accounting Firm is said to be large if the office is affiliated with the Big-4 KAP and conversely a Public Accounting Firm is said to be small if the office is not affiliated with the Big-4 KAP.

Big KAPs (Big-4) can be said to be more independent than small KAPs (Non Big-4). This is because large auditors have higher incentives (income) so that they will issue more accurate reports in the sense that large auditors will be better able to cope with pressure from managers if there are differences of opinion in financial reports because they have a more valuable reputation, and they will be more have many clients.

$H_{5}$ : The size of the public accounting firm has a significant positive effect on the Integrity of Financial reports

\section{RESEARCH METHODOLOGY}

This research is a quantitative research. The location of this research was conducted in the Indone- 
sia Stock Exchange (IDX). The data used in this study is the financial reports of companies that have gone public. Companies that have gone public are the author's choice because their financial reports are published so that it is easy to get data and use it for research. Figure 1 shows the concept of a framework variable that will examine the different corporate governance variables good (Good Corporate Governance) which is proxied by ownership institutional, audit committee, and independent commissioners, Earnings Management, and Public Accounting Firm Size (KAP) on the Integrity of Financial Report.

The population used in this study are mining companies listed on the Indonesia Stock Exchange (IDX). The sample of the population used in 2015-2019 with certain criteria. The reason the researcher uses the 2015-2019 period is because in the study it is recommended to update and at least 4 years. There are 22 samples of mining companies that meet the criteria in this study. The criteria used for sampling in this study are as follows:

1. Mining companies listed on the Indonesia Stock Exchange (IDX).

2. Mining companies that publish audited annual financial reports on the Indonesia Stock Exchange (IDX).

3. Mining companies that have institutional ownership, independent commissioners, audit committees and who meet the requirements.

4. Mining companies reported using dollars. The reason the researcher uses financial report reported in dollars is because more companies use this currency than the rupiah currency. If the researcher uses the rupiah currency, it will reduce the existing sample.

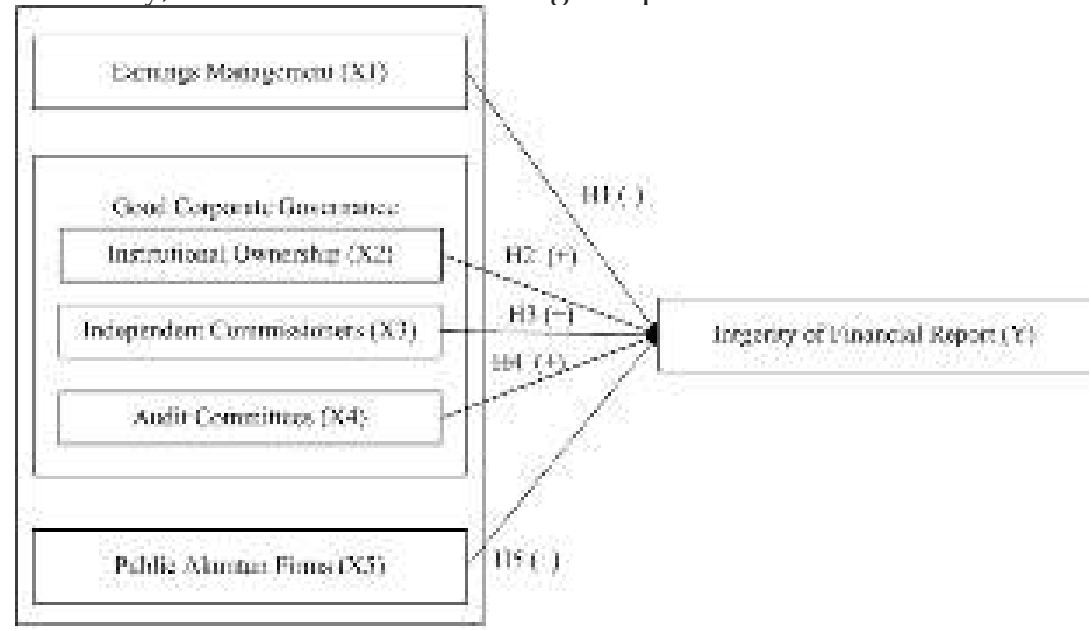

Figure 1. The Variables Conceptual Framework

Earnings management is an opportunistic behavior carried out by a manager by playing with numbers in the financial report in accordance with the objectives to be achieved, which behavior will affect reported earnings. Measurements using the Modified Jones Discretionary Accruals theory (Lubis, Fujianti, \& Amyulianthy, 2018) are explained as follows:

A. Measuring Total Accrual which is calculated by the formula:

$T A C_{i t}=N I_{i t}-C F O_{i t}$

Information :

TAC $_{\text {it }} \quad$ : Total accruals of company $\mathrm{i}$ in period $\mathrm{t}$

$\mathrm{NI}_{\text {it }} \quad$ : Net profit of company $\mathrm{i}$ in period $\mathrm{t}$

$\mathrm{CFO}_{\text {it }} \quad$ : Cash flow from operating activities of company $\mathrm{i}$ in period $\mathrm{t}$

B. Calculating the Accrual Value estimated with the OLS (Ordinary Least Square) regression equation is calculated by the formula: 
$\frac{T A C_{i K}}{A_{i L-1}}=\beta_{1}\left(\frac{1}{A_{i-1}}\right)+\beta_{2}\left(\frac{M E V}{A_{i L-1}}\right)+\beta_{2}\left(\frac{M P E_{i K}}{A_{i L-1}}\right)$

Information:

$\mathrm{TAC}_{i t} \quad$ : Total accruals of company $\mathrm{i}$ in period $\mathrm{t}$

$A_{i t-1} \quad:$ Total assets of company $i$ in period $t$

$\triangle \mathrm{REV} \quad$ : Current period company revenue - last year's company revenue

PPE $_{\text {it }} \quad$ : Total fixed assets of company $i$ in period $t$

C. Calculating Non-Discretionary Accrual is calculated by the formula:

$$
N D A_{i t}=\beta_{1}\left(\frac{1}{A_{i L-1}}\right)+\beta_{2}\left(\left(\frac{\Delta A E U}{A_{i L-1}}\right)-\left(\frac{A R E C}{A_{i L-1}}\right)\right)+\beta_{3}\left(\frac{F P E_{i L}}{A_{i L-1}}\right)
$$

Information :

NDA $_{\text {it }} \quad$ : Non-Discretionary Accruals of company $\mathrm{i}$ in period $\mathrm{t}$

$\triangle \mathrm{REV} \quad$ : Current period company revenue - last year's company revenue

$\triangle$ REC $\quad$ : Current period accounts receivable - company receivables

$\mathrm{PPE}_{\mathrm{it}} \quad$ : Total fixed assets of company $\mathrm{i}$ in period $\mathrm{t}$

D. Calculating the value of Discretionary Accruals, calculated by the formula:

$$
D A_{\text {it }}=\left(\frac{T A C_{i 1}}{A_{i t-1}}\right)-N D A_{i t}
$$

Information:

$\mathrm{DA}_{\mathrm{it}} \quad$ : Discretionary Accruals of company $\mathrm{i}$ in period $\mathrm{t}$

$\mathrm{TAC}_{i t} \quad$ : Total accruals of company $\mathrm{i}$ in period $\mathrm{t}$

$\mathrm{A}_{\mathrm{it}-1} \quad$ : Total assets of company $\mathrm{i}$ in period $\mathrm{t}$

$\mathrm{NDA}_{\text {it }} \quad$ : Non-Discretionary Accruals of company $\mathrm{i}$ in period $\mathrm{t}$

Institutional ownership is measured by using the percentage of the number of shares owned by the institution to the total outstanding shares of the company. Calculated using the following formula:

$$
\text { Inst. Ownership }=\frac{\text { mumber of ahares wnad by the Institutional }}{\text { Total shares wtotanding }} \times 100 \%
$$

Independent Commissioners are measured using the number of members of the board of commissioners from outside the company against the entire board of commissioners of the company. Calculated using the following formula:

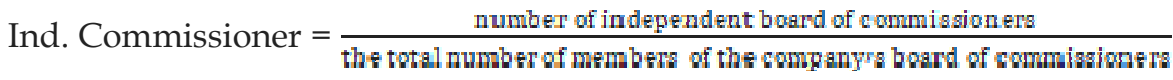

The audit committee is measured using the number of audit committees in a company. The measurement of the KAP variable uses a dummy variable. KAPs are classified into two, namely big-four KAP's and non-big-four KAP's. The integrity of financial report is the information contained in the financial report in financial report that are presented fairly, unbiased and honestly in presenting the information. The integrity of financial report is proxied by accounting conservatism. Conservatism is a precautionary principle. The concept of conservatism is applied in measuring the integrity of financial report because conservatism is a principle in the preparation of financial report that applies prudential measures so that the risk is smaller than overstate financial report Dewi dan Putra (2016) in (Fikri \& Suryani, 2020, p. 137). 
Reporting based on the precautionary principle will provide the best benefits for all users of financial report, Savitri (2016) in (Fikri \& Suryani, 2020). In this study, conservatism was calculated using the Givoly and Hayn model (Indrasari, Yuliandhari, \& Triyanto, 2016) described using the following formula:

Information:

$$
\operatorname{CONACC}_{i t}=\mathrm{NI}_{\mathrm{it}}+\text { Dep }-\mathrm{CFO}_{i t}
$$

$\begin{array}{ll}\mathrm{CONACC}_{\mathrm{it}} & : \text { Conservatism level of firm } \mathrm{i} \text { in period } \mathrm{t} \\ \mathrm{NI}_{\mathrm{it}} & : \text { Net profit plus depreciation of company } \mathrm{i} \text { in period } \mathrm{t} \\ \mathrm{CFO}_{\text {it }} & : \text { Cash Flow from operational activities of company } \mathrm{i} \text { in period } \mathrm{t}\end{array}$

This study uses Panel Data Regression Analysis. Panel data is a combination of time series data and cross section data (Basuki, 2014). According to Agus Widarjono (2009) in Basuki (2014, p. 54) the advantage of using panel data in a study is that panel data is a combination of two time series data and a cross section which is able to provide more data so that it will produce a higher degree of freedom. greater than. This analysis is used to determine the relationship between the dependent variable of integrity of financial report and other independent variables which in this study covers a 5 year research period.

This study also uses the Classical Assumption Test which is a test on the estimation model that useful for knowing whether there are deviations from the classical assumptions, so a test is needed to find out the extent of the classical assumptions fulfilled. Classical assumption tests used include normality test, autocorrelation test, multicollinearity test, heteroscedasticity test.

\section{RESULTS AND DISCUSSION}

The following is the result of panel data estimation using the Common effect model (CEM) on the effect of earnings management (MNJ_LABA), institutional ownership (KEP_INST), independent commissioners (KOM_IND), audit committee (KOM_AUDIT), and size of public accounting firm (UK_KAP) on integrity financial report (ILK).

Table 1. Statistic Descriptif

\begin{tabular}{|c|c|c|c|c|c|}
\hline & ILK & $\begin{array}{l}\mathrm{MN} \\
\text { J_LABA }\end{array}$ & $\begin{array}{l}\text { KE } \\
\text { P_INST }\end{array}$ & $\begin{array}{l}\text { KO } \\
\text { M_IND }\end{array}$ & $\begin{array}{c}\text { KOM } \\
\text { _AUDIT }\end{array}$ \\
\hline & - & 4.41 & 0.6 & 0.3 & 3.072. \\
\hline Mean & 62047586 & E-06 & 41033 & 97547 & 727 \\
\hline Me- & - & 2.03 & 0.6 & 0.4 & 3.000 . \\
\hline dian & 11148615 & E-06 & 50169 & 00000 & 000 \\
\hline Max- & 2.17 & 0.00 & 0.9 & 0.6 & 4.000 . \\
\hline imum & $E+08$ & 0101 & 70000 & 66667 & 000 \\
\hline Min- & - & - & 0.1 & 0.2 & 1.000 . \\
\hline imum & $7.21 \mathrm{E}+08$ & 4.66E-05 & 46339 & 00000 & 000 \\
\hline Std. & 1.69 & 1.94 & 0.2 & 0.1 & 0.3997 \\
\hline Dev. & $E+08$ & E-05 & 03499 & 01203 & 50 \\
\hline & - & 1.64 & - & 0.7 & - \\
\hline Skewness & 2.148.151 & 1.355 & 0.188547 & 05192 & 0.265848 \\
\hline Kur- & 7.93 & 9.29 & 2.1 & 3.5 & 1.086. \\
\hline tosis & 1.482 & 1.790 & 53.260 & 46.880 & 980 \\
\hline & 1.96 & 2.30 & 3.9 & 1.0 & 2.851. \\
\hline Jarque-Bera & 0.646 & 8.295 & 37.851 & 48.786 & 585 \\
\hline & 0.00 & 0.00 & 0.1 & 0.0 & 0.0000 \\
\hline Probability & 0000 & 0000 & 39607 & 05279 & 00 \\
\hline & - & 0.00 & 7.0 & 4.3 & 3.380 . \\
\hline Sum & $6.83 E+09$ & 0485 & 51.362 & 73.016 & 000 \\
\hline
\end{tabular}




\begin{tabular}{cccrcr} 
Sum & 3.11 & 4.11 & 4.5 & 1.1 & 1.741. \\
Sq. Dev. & E+18 & E-08 & 13.879 & 16.380 & 818 \\
\hline Ob- & & & 11 & & \\
servations & 110 & 110 & 0 & 110 & 110 \\
\hline
\end{tabular}

Source: Data processed Eviews 9.0, 2021

Table 1 describes the descriptive statistics in this study. The dependent variable in this study shows that the integrity of financial report in 2015-2019 centered on the number $62,047,586 \pm 168,916,460$. This matter shows that data on the integrity of financial report varies widely, because the standard deviation value is greater than the average value so that in 2015-2019. The integrity of the financial report is centered on the value of $62,047,586 \pm 168,916,460$.

Table 2. Chow Test

\begin{tabular}{|c|c|c|c|}
\hline Effect Test & Statistic & d.f. & Prob. \\
\hline Cross-section F & 0.619704 & $(21,61)$ & 0.8880 \\
\hline $\begin{array}{l}\text { Cross-section Chi- } \\
\text { square }\end{array}$ & 17.017222 & 21 & 0.7101 \\
\hline
\end{tabular}

Sumber: Data diolah dengan Eviews 9.0, 2021

Model selection test is a step that must be done before enter the panel data regression analysis stage to determine which model is most suitable for the data to be processed. The results of the model selection test are as follows: Chow test is carried out to test which model is suitable for use, whether common effect or fixed effect. Based on table 2, the results of the Chow test above can be seen that the value of cross section probability is 0.8880 or $>0.05$, then 0 is accepted and rejects 1 so it will use the common effect model.

Table 3. Hausman Test

\begin{tabular}{rccc}
\hline Effect Test & Statistic & d.f. & Prob. \\
& & & \\
\hline Cross-section & 8.189061 & 5 & 0.1461
\end{tabular}

Random

Source: Data processed Eviews 9.0, 2021

The Hausman test is carried out to test which model is suitable for use. whether fixed effect or Random effect model. Based on table 3, the results of the Hausman test above can be seen that the value of cross section probability is 0.1461 or 0.05 , then 0 is accepted and rejects 1 so it will use the random effect model. Due to there are differences in the results obtained by each test, then the test is used lagrange multiplier to strengthen which model is most used for the next test.

Table 4. Lagrange Multiplier Test

\begin{tabular}{cccc}
\hline \multicolumn{3}{c}{ Test Hypothesis } \\
\hline Cross- & $\mathrm{T}$ & Bo \\
\hline
\end{tabular}




\begin{tabular}{cccc} 
& section & ime & th \\
\hline $\begin{array}{c}\text { Breusch } \\
\text { Pagan }\end{array}$ & 1.908932 & \multicolumn{1}{c}{1} & 3. \\
& $(0.1671)$ & $0.2715)$ & 0774 \\
\hline
\end{tabular}

Source: Data processed Eviews 9.0, 2021

The Lagrange Multiplier test is used to determine whether the model random effect is better than the common effect model. In table 4 , it states that the results of the Lagrange multiplier test above can be it can be seen that the probability value of the cross section is 0.1671 or $>0.05$, then 0 accepted and rejected 1 so that it will use the common effect model.

Table 5. Normalitas Test

\begin{tabular}{cc}
\hline Jarque Bera & 3.675407 \\
\hline Probabilitas & 0.159183 \\
\hline Source: Data processed Eviews 9.0, 2021 &
\end{tabular}

Normality test is a test that aims to test whether regression model, confounding variables or residuals have a normal distribution. Table 5 states that the data is normally distributed.

Table 6. Autokorelasi Test

\begin{tabular}{cc}
\hline Obs*R-square $^{*}$ & 5.854295 \\
\hline Prob. Chi-Square & 0.535
\end{tabular}

Source: Data processed Eviews 9.0, 2021

Autocorrelation test is a test that aims to test Does the linear regression model have a correlation between the confounding error on period $t$ with a nuisance error in period $t-1$ (previous), if If there is a correlation, then there is an autocorrelation problem. From table 6 above, an autocorrelation test is produced which states that there is no autocorrelation.

Table 7. Multikolonieritas Test

\begin{tabular}{cc}
\hline Variabel & VIF \\
\hline Mnj_laba & 1.011837 \\
\hline Kep_inst & 1.286581 \\
\hline Kom_ind & 1.020942 \\
\hline Kom_audit & 1.071659 \\
\hline Uk_kap & 1.234127 \\
\hline
\end{tabular}


Source: Data processed Eviews 9.0, 2021

The multicollinearity test is a test that aims to test Does the regression model find a correlation between the independent variables. From table 7 above is the result of the autocorrelation test, which in the table above it is stated that there is no problem multicollinearity or free from symptoms of multicollinearity.

Table 8. Heterokedastisitas Test

$\begin{array}{lc}\text { Obs*R-square } & 7.748699 \\ \text { Prob. Chi-Square } & 0.1706\end{array}$

Source: Data processed Eviews 9.0, 2021

Heteroscedasticity test is a test that aims to test whether in the regression model there is an inequality of variance from the residual one one observation to another. From table 8 above, it is produced which states that the research data is homoscedastic or does not occur heteroscedasticity, so it can be stated the data of this study met the assumption of heteroscedasticity.

Table 9. Common Effect Model Estimation Results

\begin{tabular}{ccccc}
\hline $\begin{array}{c}\text { Varia- } \\
\text { ble }\end{array}$ & $\begin{array}{c}\text { Co- } \\
\text { efficient }\end{array}$ & $\begin{array}{c}\text { Std } \\
\text {. Error }\end{array}$ & $\begin{array}{c}\text { T- } \\
\text { Statistic }\end{array}$ & \multicolumn{2}{c}{ Pro } \\
b.
\end{tabular}

Source: Data processed Eviews 9.0, 2021

$\mathrm{T}$ statistical test is used to determine the effect of the independent variable individually (partial) in explaining the variation of the dependent variable. T-test is done by comparing the results of the $\mathrm{p}$-value with a critical value or significance of $1 \%, 5 \%$ or $10 \%$. If the p-value $>0.05$, it means that there is no significant individual effect of the independent variable on the dependent variable and vice versa if the $p$ value $<0.05$ indicates that there is a significant individual influence of the independent variable on the dependent variable. The following are the results of the partial significance test:

\begin{tabular}{ccccc}
\hline Varia- & Co- & T- & Pr & Hy- \\
\hline
\end{tabular}




\begin{tabular}{|c|c|c|c|c|c|}
\hline ble & efficient & Statistic & ob. & & pothesis \\
\hline MNJ_L & 5.84 & 1.260 .99 & & 0.2 & $\operatorname{Re}-$ \\
\hline $\mathrm{ABA}$ & $E+11$ & 3 & 109 & & jected \\
\hline KEP_IN & 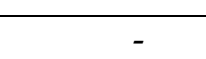 & - & & 0.0 & $\operatorname{Re}-$ \\
\hline ST & $1.25 \mathrm{E}+09$ & 4.814 .306 & 000 & & jected \\
\hline KOM_I & 1.58 & & & 0.3 & $\operatorname{Re}-$ \\
\hline ND & $E+08$ & $0.935 \% 41$ & 522 & & jected \\
\hline $\mathrm{KOM}_{-}$ & 8.33 & 2.180 .49 & & 0.0 & Ac- \\
\hline AUDIT & $E+07$ & 9 & 321 & & cepted \\
\hline \multirow[t]{2}{*}{ UK_KA } & 1.47 & & & 0.8 & $\operatorname{Re}-$ \\
\hline & $E+07$ & 0.161727 & 719 & & jected \\
\hline
\end{tabular}

Table 10. Partial Test Results

Source: Data processed Eviews 9.0, 2021

Based on the results of the partial test using Eviews 9.0 software for the earnings management variable (MNJ_LABA), it can be concluded that earnings management has an insignificant positive effect on the increase in the integrity of financial report. The results of this study support the research conducted by Lubis, Fujianti, \& Amyulianthy (2018), that earnings management has no significant positive effect, which means that higher earnings management will affect the high integrity of financial report. These results indicate that earnings management is one of the methods used by stakeholders in the preparation of financial report as the financial report become a communication tool for internal parties to external parties aimed at maintaining good performance in the eyes of stakeholders and investors in order to strengthen stock prices (Priantinah, 2016). Financial report are more reliable if the financial report are conservative and not overstate so that the information presented in the financial report does not cause harm to the party using the the accounting information. So that researchers use conservatism in measuring the integrity of financial report.

The results of the partial test using Eviews 9.0 software for the institutional ownership variable (KEP_INST), it can be concluded that institutional ownership has a significant negative effect on the integrity of financial report. This means that high institutional ownership will result in a decrease in the integrity of financial report, because they are still not able to carry out supervision of manager performance to realize financial report with integrity so that the higher institutional ownership, it will reduce the integrity of financial report.

The results of the partial test using Eviews 9.0 software for the independent commissioner variable (KOM_IND), it can be concluded that institutional ownership has an insignificant positive effect on the integrity of financial report. So this study has not succeeded in proving the third hypothesis of this study which states that the high level of independent commissioners will affect the level of integrity of financial report. Independent commissioners are measured using the percentage of the number of members of the board of commissioners who come from outside the company to the entire board of commissioners of the company. The positive direction of the coefficient indicates that the higher the percentage of independent commissioners, the higher the integrity of financial report will be. The results of this study support the research conducted by Mirda and Sri, (2014) which states that independent commissioners have an insignificant positive effect on the integrity of financial report.

The results of the partial test using Eviews 9.0 software for the audit committee variable (KOM_AUDIT), it can be concluded that the audit committee has a significant positive effect on the integrity of financial report. The results of this study are in line with previous research conducted by Siahaan, (2017), Awalin, et al (2020), Fikri \& Suryani, (2020), and Istiantoro, et al (2017), which stated that 
the audit committee had a significant positive effect on integrity financial report. This is because the number of audit committees affects the integrity of the financial report. The number of audit committees that are believed to be capable of optimally supervising the process of making financial report. That way, the existence of an audit committee is believed to make the company more effective and efficient.

The results of the partial test using Eviews 9.0 software for the variable size of the public accounting firm (UK_KAP), it can be concluded that the size of the public accounting firm has a positive and insignificant effect on the integrity of financial report. The results of this study support the research conducted by Lubis, Fujianti, \& Amyulianthy, (2018) and Qoyyimah, et al (2015) stating that the size of a public accounting firm has a positive and insignificant effect on the integrity of financial report. The small influence of the size of the public accounting firm on the integrity of financial report is because in its application, the big-four KAP or non-big-four KAP both have standards that are in accordance with the Professional Standards of Public Accountants (SPAP) at the time of auditing the company's financial report.

\section{CONCLUSIONS, LIMITATIONS AND SUGGESTIONS}

Based on the results of panel data regression analysis partially, the effect can be seen as follows: Earnings management variable has no significant effect on the integrity of financial report if other variables are considered constant. It is because in the information perspective it is stated that earnings management is not part of fraud, but rather it is a manager's freedom in choosing and using certain accounting methods, which are still within limits in accordance with generally accepted accounting principles and procedures (Generally Accepted Accounting Principles).

Institutional ownership variable has no significant effect on the integrity of financial reports if other variables are held constant. This is because the higher the value of institutional ownership, the manager will be more interested in the size of the shares invested, so that the management has the right to regulate financial reports which triggers management to carry out earnings management, so this will affect the decline in the value of financial report integrity.

The independent commissioner variable has no significant effect on the integrity of the financial reports if other variables are held constant. It happens because, the average value of independent commissioners in mining companies for the 2015-2019 period is only 39\%, which is considered that independent commissioners are less able to provide too much oversight to management actions and actions in the integrity of financial reports, because The duties of independent commissioners are centered on oversight of corporate governance. Therefore, it can be said that independent commissioners do not directly affect the part in the act of integrity of financial reports.

The audit committee variable has a significant effect on the integrity of the financial reports if other variables are held constant. It happens because the number of audit committees is believed to be capable of maximally supervising the process of making financial reports.

The variable size of the public accounting firm has no significant effect on the integrity of financial reports if other variables are held constant. It happens because, in its application, the high and low integrity of financial reports can be assessed from two perspectives, namely from the manager's performance and also from the KAP, so that the overall size of the public accounting firm cannot prove that the financial reports audited by the big-four KAP can affect the high level of integrity of financial reports therefore, the resulting effect is not material.

Future research is expected to expand the research sample. In this study, only mining companies that where most of the financial report do not meet the criteria sample and most of them suffer losses, so the data is lacking varied, and the number of samples is small, it is better for the next researcher using other companies whose total losses and profits are balanced and have the appropriate sample criteria so that the total enough samples. 


\section{DAFTAR PUSTAKA}

Awalin, R., Mahsuni, A., \& Hariri. (2020). Pengaruh Reputasi Akuntan Publik dan Komite Audit terhadap Laporan Integritas Keuangan dengan Pemoderasi Corporate Governance. E-JRA. Volume 9 No. 05, 34.

Basuki, A. T. (2014). Regresi Model PAM, ECM dan Data Panel dengan EVIEWS 7. Yogyakarta: Katalog Dalam Terbitan.

Fikri, M., \& Suryani, E. (2020). Pengaruh Good Corporate Governance Terhadap Integritas Laporan Keuangan (Studi pada Perusahaan BUMN yang terdaftar di BEI Periode 2014-2018). Jurnal Akuntansi, Vol. 8, No. 2. ISSN 2337-4314, 139.

Hasanuddin. (2020). Analisis Terhadap Faktor-Faktor Penentu Tercapainya Integritas Suatu Laporan Keuangan. Pasuruan: CV. Penerbit Qiara Media.

Indrasari, A., Yuliandhari, W. S., \& Triyanto, D. N. (2016). Pengaruh Komisaris Independen, Komite Audit, dan Financial Distress Terhadap Integritas Laporan Keuangan. Jurnal Akuntansi, Vol. XX, N0. 01, 120.

Irawati, L., \& Fakhruddin, I. (2016). Pengaruh dan Kualitas Audit Corporate Governance terhadap Integritas Laporan Keuangan. KOMPARTEMEN, Vol. XIV, No. 1, 102-103.

Istiantoro, I., Paminto, A., \& Ramadhani, H. (2017). Pengaruh Struktur Corporate Governance terhadap Integritas Laporan. AKUNTABEL, Vol. 14, No.2, 173-176.

Jensen, M. C., \& Meckling, W. H. (1976). Theory of The Firm : Managerial Behavior, Agency Costs and Ownership Structure. Journal of Financial Economics 3, 308 .

Khatijah, S. (2019). Pengaruh Good Corporate Governance dan Manajemen Laba Terhadap Integritas Laporan Keuangan Pada Perusahaan Manufaktur Yang Terdaftar pada Bursa Efek Indonesia Tahun 2013-2016. 16.

Lubis, I. P., Fujianti, L., \& Amyulianthy, R. (2018). Pengaruh Ukuran KAP, Ukuran Perusahaan dan Manajemen Laba terhadap Integritas Laporan Keuangan. ULTIMA Accounting ISSN 2085-4595, 147.

Mirda, R. S., \& Sri, R. (2014). Analisis Pengaruh Independensi Auditor, Mekanisme Corporate Governance, Kualitas Audit, dan Manajemen Laba Terhadap Integritas Laporan Keuangan (Studi Empiris pada Perusahaan Manufaktur yang Terdaftar di Bursa. Proceedings SNEB 2014, 5.

Nelly, Y. (2016). Pengaruh Komisaris Independen, Komite Audit, Leverage, Pergantian Auditor, dan Spesialisasi Industri Auditor Terhadap Integritas Laporan Keuangan. JOM Fekom Vol. 3 No. 1, 422.

Priantinah, D. (2016). Perspektif Oportunistik dan Efisiensi dalam Fenomena Manajemen Laba. Journal of Accounting, Volume 16 hal: 3-4.

Priharta, A. (2017). Pengaruh Good Corporate Governance Terhadap Integritas Laporan Keuangan. Journal of Applied Business and Economics Vol. 3 No. 4, 245.

Qoyyimah, S. D., Kholmi, M., \& Harventy, G. (2015). Pengaruh Struktur Corporate Governance, Audit Tenure dan Ukuran KAP Terhadap Integritas Laporan Keuangan. Jurnal Reviu Akuntansi dan Keuangan, 788.

Rahmawati, S. (2017). Konflik Keagenan dan Tata Kelola Perusahaan di Indonesia. Banda Aceh: Syiah uala University Press.

Sarwono, J. (2006). Metode Penelitian Kuantitatif dan Kualitatif. Yogyakarta: Graha Ilmu.

Siahaan, S. B. (2017). Pengaruh Good Corporate Governance dan Kualitas KAP terhadap Integritas Laporan Keuangan Studi Kasus pada Perusahaan Manufaktur yang Terdaftar di Bursa Efek Indonesia. Jurnal Akuntansi dan Keuangan Methodist Vol. 1 No. 1, 85-87. 
Sugiyono. (2016). Metode Penelitian Kuantitatif, Kualitatif, dan RED. Bandung: CV. Alfabeta.

Sulistyanto, S. (2018). Manajemen Laba. Jakarta: PT.Grasindo.

Tawakal Putra, D. S., \& Muid, D. (2012). Pengaruh Independensi, Mekanisme Corporate Governance, Kualitas Audit, dan Manajemen Laba Terhadap Integritas Laporan Keuangan. Diponegoro Journal Of Accounting, Vol. 1, No 2, 10.

Wardhani, W. K., \& Samrotun, Y. C. (2020). Pengaruh Kepemilikan Institusional, Kepemilikan Manajerial, Ukuran Perusahaan dan Levergae terhadap Integritas Laporan Keuangan. Jurnal Ilmiah Universitas Batanghari Jambi. ISSN: 2549-4236, 478. Volume 20 (2). 